\title{
PENGARUH UKURAN PERUSAHAAN, LAVERAGE, PROFITABILITAS, MARKET TO BOOK RATIO, KEPEMIIKAN MAYORITAS DAN CORPORATE SOCIAL RESPONSIBILITY TERHADAP AGRESIVITAS PAJAK
}

\author{
Puji Rahayu ${ }^{1}$ Ida Nur Aeni' \\ Program Studi Akuntansi Fakultas Ekonomi dan Bisnis Universitas Muria Kudus \\ rahayupuj23@gmail.com \\ Ida.nuraeni@umk.ac.id
}

\begin{abstract}
This research meant to test the influence of the characteristic of the company and the corporate social responsibility to the aggressiveness tax of a company. Characteristic of the company uses firm size, laverage, and inventory intensity. The population of this research is the entire manufacturing companies which are listed in Indonesia Stock Exchange (IDX). The sample collection technique has been done by using purposive sampling and 32 companies have been obtained as sample criteria during 2010-2014. The hypothesis test has been done by using multiple linear regressions analysis technique. The result of this research shows that firm size, laverage, and corporate social responsibility have significant influence to the tax aggressiveness; it mean that the size of a company, liability and level of corporate social responsibility will influence the tax aggressiveness level in each company. Laverage uses debt to minimize tax burden of companies even more likely to lead aggressively against the corporation tax. Meanwhile profitability, market to book ratio and majority firm does not have any influence to the tax agggressiveness, it means company prefer to increase the profit instead of meet the tax burden and when the the company stock is decreased, investors will not invest in that company.
\end{abstract}

Keywords: Characteristic of the Company, Corporate Social Responsibility, Tax aggressiveness, Effective Tax Rate.

\section{PENDAHULUAN}

Di Indonesia besar penerimaan dari sektor pajak pada realisasi penerimaan negara tahun 2010 - 2014 baru berkisaran antara 72-78\%. Realisasi penerimaan PPh yang tidak sesuai target terjadi karena perusahaan meminimalkan beban pajak yang harus dibayarkan. Perusahaan menekan biaya dengan meminimalkan kewajiban membayar pajak karena biaya pajak akan menurunkan laba setelah pajak (after tax profit), tingkat pengembalian (rate of return), dan arus kas (cash flows) (Suandy, 2011:5).

Berkembangnya praktik penghindaran pajak ini di dukung dengan adanya perkembangan teknologi informasi didunia dan semakin terbukanya perekonomian. Suatu negara akan memberi peluang bagi perusahaan untuk mengembangkan usahanya. Berdasarkan data yang diperoleh badan usaha yang terdaftar 2.472.632 WP Badan dan hanya 1.184.816 WP Badan yang terdaftar sebagai wajib pajak badan dan yang melaporkan SPT dan membayar pajak 47.9\% dalam tahun 2015 (sumber www.pajak.go.id). 
Rendahnya kepatuhan wajib pajak badan merupakan indikasi adanya praktik penghindaran pajak yang dilakukan perusahaan demi mengurangi beban pajaknya.

Fakta di lapangan menunjukkan di mana fenomena saat ini pendapatan pemerintah dari sektor pajak belum maksimal. Pada tahun 2010 target penerimaan pajak Rp 743 triliun, yang terealisasi hanya 97,3\% atau sebesar Rp 723 triliun, tahun 2011 target sebesar Rp 879 triliun, yang terealisasi hanya 99,4\% atau sebesar Rp 874 triliun, tahun 2012 dari 1.016 triliun yang ditargetkan hanya terealisasi Rp 981 triliun atau 96,4\% saja, di tahun 2013 pun sama target $\mathrm{Rp} 1.148$ triliun yang terealisasi hanya $\mathrm{Rp} 1.077$ triliun atau prosentasenya sebesar 93,8\%, target penerimaan 2014 sebesar Rp 1.246 triliun hanya terealisasi Rp 1.143 triliun atau sebesar 91,7\%, target penerimaan tahun 2015 sebesar Rp1.489,3 triliun yang hanya terealisasi sebesar Rp1.235,8 triliun, atau 83 persen (sumber www.pajak.go.id). Dari data tersebut di ketahui bahwa upaya pemerintah dalam meningkatkan penerimaan dari sektor pajak masih kurang. Masyarakat sebagai wajib pajak masih beranggapan bahwa beban pajak akan mengurangi pendapatan yang telah di peroleh, padahal lebih dari itu pajak akan di gunakan untuk kepentingan bersama.

Darussalam (2014:69) menyatakan bahwa agresivitas pajak sebagai perencanaan pajak yang di buat untuk mengurangi beban pajak melalui transaksi yang tidak memiliki tujuan bisnis. Setiadji (dalam Utari, 2014) mengatakan bahwa selama ini perusahaan beranggapan memiliki dua beban yang sama yaitu beban pajak dan beban CSR. Pada dasarnya kedua beban tersebut di gunakan untuk mensejahterakan masyarakat. Namun agar perusahaan tidak memiliki dua beban maka perusahaan mulai mencari cara untuk meminimalkan pajak perusahaan melalui kegiatan agresivitas pajak. Perusahaan melakukan agresivitas pajak dipengaruhi oleh karakteristik perusahaan dan Corporate Social Responsibility (CSR) (Yoehana, 2013). Karakteristik perusahaan yaitu ciri khas atau sifat yang melekat dalam suatu entitas usaha yang dapat di lihat dari berbagai segi, di antaranya jenis usaha atau industri, tingkat likuiditas, tingkat profitabilitas, ukuran perusahaan (size) (Surbakti, 2012). Ukuran perusahaan menunjukan besar kecilnya perusahaan. Sebuah perusahaan yang ukuran/ skalanya besar dan sahamnya tersebar luas memiliki kekuatan tersendiri dalam menghadapi masalah bisnis dan kemampuan perusahaan untuk menghasilkan laba lebih tinggi.

Penelitian ini merupakan replikasi dari penelitian sebelumnya yaitu penelitian Kuriah dan Asyik (2016) yang meneliti tentang Pengaruh Karakteristik Perusahaan dan Corporate Social Responsibility (CSR) terhadap Agresivitas Pajak. Perbedaan penelitian ini dengan penelitian Kuriah dan Asyik (2016) terletak pada variabel, sampel dan tahun penelitian, yaitu penelitian ini menggunakan variabel independen karakteristik perusahaan, Corporate Social Responsibility, ukuran perusahaan (size), leverage, profitability, market to book 


\section{[ACCOUNTING GLOBAL JOURNAL] E ISSN}

ratio, inventory intensity dan kepemilikan mayoritas dan menggunakan ETR sebagai proxy untuk mengukur agresivitas pajak perusahaan, sampel perusahaan yang digunakan adalah perusahaan manufaktur yang terdaftar di BEI tahun 2010-2014.

\section{TINJAUAN PUSTAKA DAN PENGEMBANGAN HIPOTESIS}

\section{Landasan Teori}

\section{Teori Legistimasi (Lgitimacy Teory)}

Dowling dan Pfeffer (1975) dalam Ghozali dan Chariri (2014). Legitimasi merupakan hal yang penting bagi organisasi, batasan - batasan yang ditekankan oleh norma-norma dan nilai-nilai sosial dan reaksi terhadap batasan tersebut mendorong pentingnya analisis perilaku organisasi dengan memperhatikan lingkungannya.

\section{Teori Stakeholder (Stakeholder Teory)}

Ghozali dan Chariri (2014) Stakeholder theory mengatakan bahwa perusahaan bukanlah entitas yang hanya beroperasi untuk kepentingan sendiri namun harus memberikan manfaat bagi stakeholdernya (pemegang saham, kreditor, konsumen, supplier, pemerintah, masyarakat, analis, dan pihak lain).

\section{Agresivitas Pajak}

Agresivitas pajak sebagai kegiatan perencanaan pajak semua perusahaan yang terlibat dalam usaha mengurangi tingkat pajak yang efektif (Hlaing, 2012).

\section{Karakteristik Perusahaan}

Karakteristik perusahaan merupakan ciri khas atau sifat yang melekat pada suatu entitas usaha (Surbakti, 2012). Karakteristik perusahaan dapat dilihat dari beberapa segi, di antaranya jenis usaha atau industri, tingkat likuiditas, profitabilitas perusahaan, finansial laverage dan kepemilikan saham, ukuran perusahaan dan lain-lain.

\section{Ukuran Perusahaan}

Ukuran perusahaan menunjukkan besar atau kecilnya kekayaan (aset) yang dimiliki suatu perusahaan. Perusahaan yang besar tentunya juga mempunyai pengalaman yang lebih banyak dalam menjalakan kegiatan operasinya, dan memiliki kematangan yang lebih dalam strategi untuk kelangsungan operasinya, termasuk strategi penghematan pajak (Kristanto,2013).

\section{Laverage}


Leverage adalah salah satu rasio keuangan yang menggambarkan hubungan antara hutang perusahaan terhadap modal maupun aset perusahaan. Perusahaan yang menggunakan hutang akan menimbulkan adanya bunga yang harus di bayar. Besar kecilnya laverage pada perusahaan dapat mempengaruhi besar kecilnya pajak yang dibayarkan perusahaan.

\section{Profitabilitas}

Menurut Ardyansah (2014) profitabilitas adalah kemampuan perusahaan menghasilkan keuntungan dari aktivitas bisnisnya. Profitabilitas adalah alat ukur kinerja manajemen dalam mengelola kekayaan perusahaan yang dilihat dari laba perusahaan.

\section{Market To Book Rasio}

Market to Book Ratio (rasio nilai pasar dengan nilai buku) adalah rasio nilai pasar ekuitas saham perusahaan dengan nilai akuntansi ekuitas itu. Bila market tobook ratio relatif tinggi dibandingkan rata-rata industri maka hal itu menunjukkan bahwa perusahaan dapat lebih efisien menggunakan asetnya untuk menciptakan nilai.

\section{Kepemilikan Mayoritas}

Hidayanti (2013) menyatakan bahwa perusahaan dengan kepemilikan keluarga lebih efisien daripada perusahaan yang dimiliki publik karena biaya pengawasan yang dikeluarkan atau monitoring cost nya lebih kecil.

\section{Corporate Social Responsibility}

Corporate Social Responsibility adalah salah satu kegiatan yang harus dilaksanakan oleh suatu perusahaan yang menginginkan agar kegiatan usaha yang dilaksanakan dapat berjalan lancar dan berkesinambungan.

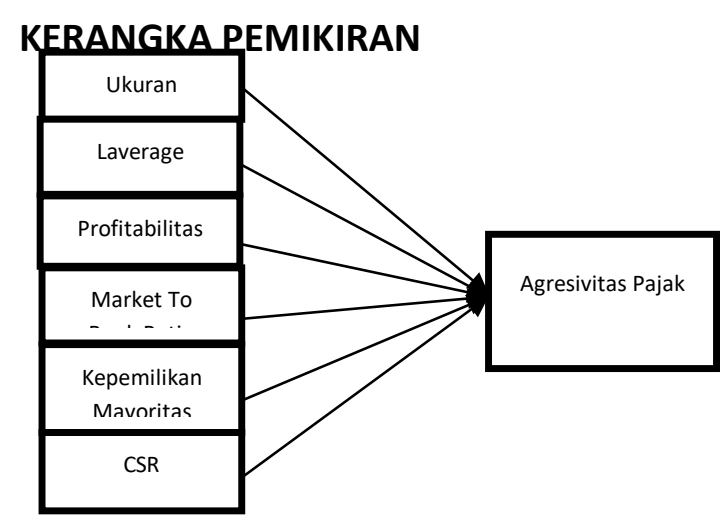




\section{Pengembangan Hipotesis}

$\mathrm{H}_{1}$ : Ukuran Perusahaan berpengaruh positif terhadap Agresivitas Pajak

$\mathrm{H}_{2}$ : Laverage berpengaruh negatif terhadap Agresivitas Pajak.

$\mathrm{H}_{3}$ : Profitabilitas berpengaruh positif terhadap Agresivitas Pajak

$\mathrm{H}_{4}$ : Market ToBook Ratio berpengaruh negatif terhadap Agresivitas Pajak

$\mathrm{H}_{5}$ : Kepemilikan Mayoritas berpengaruh positif terhadap Agresivitas Pajak.

$\mathrm{H}_{6:}$ Corporate Social Responsibility berpengaruh negatif terhadap Agresivitas Pajak.

\section{Metode Penelitian}

\section{Definisi Operasional Variabel dan Pengukuran}

\section{Agresivitas pajak}

Agresivitas pajak adalah keinginan perusahaan untuk meminimalkan beban pajak yang dibayar dengan cara yang legal, ilegal, maupun kedua-duanya. Adapun yang menjadi proksi utama dalam penelitian ini mengacu pada penelitian Lanis dan Richardson (2011) adalah Effective Tax Rate (ETR) yang dihitung dari:

$$
E T R=\frac{\text { Beban Pajak Penghasilan }}{\text { Pendapatan Sebelum Pajak }}
$$

ETR menggambarkan prosentase total beban pajak penghasilan yang dibayarkan perusahaan dari seluruh total pendapatan sebelum pajak yang diperoleh perusahaan.

\section{Ukuran Prusahaan}

Ukuran perusahaan menggambarkan besar kecilnya perusahaan yang di lihat melalui total aset yang dimiliki. Ukuran perusahaan menurut Lanis dan Richardson (2012), dapat diukur dengan logaritma natural total aset dengan rumus sebagai berikut:

$$
\text { Size }=\text { Ln Total Asset }
$$

\section{Laverage}

Leverage menggambarkan proporsi hutang jangka panjang terhadap total aset yang dimiliki perusahaan. Leverage diukur dengan menggunakan debtratio (rasio total hutang) yaitu perbandingan total hutang baik hutang lancar maupun hutang jangka panjang dengan total aktiva. Menurut Kasmir (2014:156) laverage diukur dengan rasio total utang yaitu dapat dirumuskan sebagai beikut:

$$
\text { Rasio Total Hutang }=\frac{\text { Total Utang }}{\text { Total Aset }}
$$




\section{Profitabilitas}

Profitabilitas menggambarkan kemampuan perusahaan dalam memperoleh laba. Penelitian ini menggunakan ROA sebagai proksi untuk mengukur profitabilitas. ROA diukur dengan menggunakan proksi model Lanis dan Richardson (2012), yaitu:

$$
R O A=\frac{\text { pendapatan sebelum pajak }(\text { EBIT })}{\text { total aset }}
$$

\section{Market To Book Rasio}

Market to book ratio digunakan untuk mengukur seberapa besar pertumbuhan perusahaan di masa depan. Pertumbuhan perusahaan merupakan kemampuan perusahaan untuk memperoleh investasi dimasa depan. Menurut Lanis dan Richardson (2012), Market to book ratio dapat diukur dengan rumus sebagai berikut:

$$
M T B=\frac{\text { Nilai Pasar }}{\text { Nilai Buku }}
$$

\section{Kepemilikan Mayoritas}

Pengukuran kepemilikan mayoritas yang digunakan dalam penelitian ini adalah kepemilikan baik secara langsung maupun tidak langsung. Kepemilikan langsung adalah kepemilikan dari keluarga yang juga menjadi pihak manajemen, sedangkan tidak langsung adalah kepemilikan seseorang melalui perusahaan non public yang dimiliki seseorang tersebut melalui kepemilikan pada proporsi saham.

\section{Corporate Social Responsibility}

Corporate Social Responsibility (CSR) pengukuran ini dilakukan dengan mencocokan item pada checklist dengan item yang diungkapkan perusahaan. Setelah mengidentifikasi item yang diungkapkan oleh perusahaan di dalam laporan tahunan, serta mencocokannya pada checklist hasil pengungkapan item yang diperoleh dari setiap perusahaan dihitung indeksnya dengan proksi CSRI. Adapun rumus untuk menghitung CSRI adalah sebagai berikut:

$$
\text { CSRIi }=\frac{\sum \mathrm{Xi}}{\mathrm{n}}
$$

\section{Populasi Penelitian}

Populasi adalah wilayah generalisasi yang terdiri atas obyek/subyek yang mempunyai kualitas dan karakteristik tertentu yang ditetapkan oleh peneliti untuk dipelajari dan kemudian ditarik kesimpulannya (Sugiyono, 2014:61). Berdasarkan kualitas dan ciri tersebut, 
populasi dapat dipahami sebagai sekelompok obyek pengamatan yang minimal memiliki satu persamaan karakteristik. Populasi dalam penelitian ini adalah perusahaan manufaktur yang terdaftar di Bursa Efek Indonesia pada periode 2010-2014 yang memiliki jumlah 147 perusahaan (www.idx.co.id).

\section{Sampel Penelitian}

Sugiyono (2014) Pengambilan sampel dalam penelitian ini dilakukan dengan menggunakan metode Purposive sampling. Metode purposive sampling adalah pengambilan sampel berdasarkan pada kesesuaian karakteristik dengan kriteria sampel yang ditentukan agar diperoleh sampel yang respresentatif. Dari purposive sampling yang di gunakan di dapat 7 perusahaan di BEI sebagai sampel penelitian.

\section{Pengumpulan Data}

Teknik pengumpulan data dalam penelitian ini adalah dengan menggunakan metode dokumentasi dan studi pustaka. Dalam penelitian ini dokumentasinya berupa laporan tahunan dan laporan keuangan audit perusahaan manufaktur yang terdaftar di Bursa Efek Indonesia (BEI). Serta melakukan studi pustaka yaitu telaah pustaka yang ditujukan untuk mendapatkan informasi yang berhubungan dengan materi penelitian melalui berbagai literature serta media yang mendukungnya.

Metode dokumentasi merupakan teknik pengambilan data dengan cara mencari dan mengumpulkan data yang diperoleh dari laporan tahunan yang sudah dipublikasikan oleh perusahaan manufaktur yang terdaftar di Bursa Efek Indonesia 2010-2014. Metode dokumentasi dapat melakukan pengumpulan data dengan cara menggandakan data yang ada atau dengan cara membuat salinan.

\section{Analisis Data}

\section{Analisis Statistik Deskriptif}

Statistik deskriptif adalah dari bagian statistika yang mempelajari cara pengumpulan data dan penyajian data sehingga mudah dipahami. Analisis statistik deskriptif digunakan untuk mengetahui nilai statistik atas variabel-variabel yang digunakan dalam penelitian yakni profitabilitas, laverage, ukuran perusahaan (size), inventory intensity. Dengan statistik deskriptif dapat diketahui nilai rata-rata, minimum dan standar deviasi dari variabel-variabel yang diteliti.

\section{Pengujian Asumsi Klasik}

\section{Uji Normalitas}


Uji normalitas bertujuan untuk menguji apakah dalam proses regresi, variabel terikat dan variabel bebas keduanya mempunyai distribusi normal atau tidak. Model regresi yang baik adalah memiliki distribusi data normal atau mendekati normal. Uji statistik sederhana dapat dilakukan dengan melihat nilai signifikan Kolmogrorov - Smirnov(K-S). Uji K-S ini dilakukan dengan melihat nilai probabilitas, dengan ketentuan jika nilai probabilitasnya $\geq$ 0,05 maka residual berdistribusi normal. Sementara jika nilai probabilitasnya $\leq 0,05$ maka residual berdistribusi tidak normal (Ghozali,2016).

\section{Uji Multikolonieritas}

Uji multikolineritas bertujuan untuk menguji apakah terdapat hubungan antar variabel independen dalam proses regresi (Ghozali, 2016). Karena model regresi yang baik adalah yang tidak terjadi korelasi antara variabel independen. Cut off yang umum digunakan untuk menunjukkan adanya multikolinieritas adalah nilai tolerance $\leq 0,10$ atau nilai VIF $\geq 10$ (Ghozali, 2016).

\section{Uji Autokorelasi}

Uji autokorelasi bertujuan menguji apakah dalam model regresi linier terdapat korelasi antara kesalahan pengganggu pada periode T dengan kesalahan pengganggu periode t-1 (sebelumnya). Jika terdapat korelasi maka dinamakan ada problem autokorelasi. Sementara model regresi yang baik dalam model regresi yang tidak memiliki masalah autokorelasi (Ghozali, 2016). Gejala autokorelasi dapat dideteksi dengan menggunakan uji Dubin-Watson (DW). Regresi yang baik adalah regresi yang tidak terjadi autokorelasi di dalamnya. Pengambil keputusan ada tidaknya auto korelasi melalui kriteria DW tabel dengan tingkat signifikan 5\% yaitu sebagai berikut: (1) Angka DW di bawah -2 berati tidak ada autokorelasi positif. (2) Angka DW di antara -2 berarti tidak ada autokorelasi. (3) Angka DW di atas +2 berarti ada autokorelasi negatif.

\section{Uji Heterokedastisitas}

Uji heteroskedastisitas bertujuan menguji apakah dalam model regresi terjadi ketidaksamaan variance dari residual satu pengamatan yang lain (Ghozali, 2016). Jika Variance dari residual satu pengamatan ke pengamatan lain tetap, maka disebut homoskedastisitas, jika berbeda disebut heteroskedastisitas. Untuk mengetahui mendeteksi ada tidaknya heteroskedastisitas dapat dilihat dengan uji glejser dengan meregresikan nilai seluruh variabel independen dengan nilai mutlak (absolut) dari nilai residual sehingga di hasilkan probabilitas signifikansinya di atas tingkat kepercayaan $5 \%$.

\section{Pengujian Hipotesis}




\section{Analisis Regresi Berganda}

Analisis regresi adalah metode statistika yang menjelaskan hubungan dua variabel atau lebih melalui sebuah persamaan. Tujuan pemodelan regresi adalah untuk menjelaskan hubungan antara dua atau lebih variabel serta memprediksi atau meramalkan kondisi dimasa yang akan datang. Dalam penelitian ini analisis regresi linear berganda digunakan untuk menguji pengaruh karakteristik perusahaan yaitu jimlah profitabilitasnya, laverage, size, capital intensity, inventory intensity. Adapun persamaan regresinya dirumuskan:

$P P=\alpha+\beta_{1} S Z E+\beta_{2} L E V+\beta_{3} R O A+\beta_{4} M T B+\beta_{5} K M+\beta_{6} C S R$

\section{Koefisien Determinasi $\left(\mathbf{R}^{2}\right)$}

Nilai koefisien determinasi adalah antara nol dan satu. Nilai $\mathrm{R}^{2}$ yang kecil berarti kemampuan variabel-variabel independen dalam menjelaskan variasi variabel dependen amat terbatas. Nilai yang mendekati satu berarti variabel-variabel independen memberikan hampir semua informasi yang dibutuhkan untuk memprediksi variasi variabel dependen.

\section{Uji Kelayakan Model (Uji f)}

Uji koefisien F pada dasarnya menujukan apakah semua variabel independen atau bebas yang dimasukkan dalam model mempunyai pengaruh secara bersama-sama terhadap variabel dependen atau terikat (Ghozali, 2016). Uji signifikan F dilakukan dengan menggunakan tingkat signifikan 0,05 dengan kriteria penolakan atau penerimaan hipotesis sebagai berikut: (a) jika nilai signifikan $\leq 0,05$ berarti semua variabel independen secara bersama-sama berpengaruh terhadap variabel dependen (b) jika nilai signifikan $\geq 0,05$ berarti semua variabel independen secara bersama-sama tidak berpengaruh terhadap variabel dependen.

\section{Uji Signifikan Parameter Individual (Uji t)}

Uji statistik t pada dasarnya menunjukkan seberapa jauh pengaruh satu variabel independen secara individual dalam menerangkan variasi variabel dependen (Ghozali, 2016). Adapun kriteria pengujian secara persial dengan tingkat signifikan sebesar $\alpha=5 \%$ yaitu sebagai berikut: (a) jika nilai signifikan $\leq 0,05$ berarti variabel independen secara individual berpengaruh terhadap variabel dependen (b) jika nilai signifikan $\geq 0,05$ berarti variabel independen secara individual tidak berpengaruh terhadap variabel dependen.

\section{HASIL DAN PEMBAHASAN}

\section{Hasil Uji Statistik Deskriptif}




\begin{tabular}{|l|l|l|l|l|l|}
\hline & N & Min & Max & Mean & $\begin{array}{l}\text { Std. } \\
\text { Deviatio } \\
n\end{array}$ \\
\hline $\begin{array}{l}\text { Ukuran } \\
\text { Perusahaan }\end{array}$ & 32 & 15,00 & 30,00 & $\begin{array}{l}24,000 \\
0\end{array}$ & 5,91881 \\
\hline Laverage & 32 & 0,13 & 0,70 & 0,3297 & 0,14735 \\
\hline Profitabilitas & 32 & 0,00 & 0,28 & 0,1504 & 0,08484 \\
\hline $\begin{array}{l}\text { Maket To Book } \\
\text { Rasio }\end{array}$ & 32 & 0,00 & 2,51 & 0,8484 & 0,77686 \\
\hline $\begin{array}{l}\text { Kepemilikan } \\
\text { Mayoritas }\end{array}$ & 32 & 1,00 & 1,00 & 1,0000 & 0,0000 \\
\hline $\begin{array}{l}\text { CSR } \\
\text { Agresivitas } \\
\text { Pajak }\end{array}$ & 32 & 0,22 & 0,39 & 0,2549 & 0,03479 \\
\hline $\begin{array}{l}\text { Valid N } \\
\text { (listwise) }\end{array}$ & 32 & 0,30 & 0,81 & 0,6824 & 0,17399 \\
\hline $\begin{array}{l}\text { Sumber: } \\
\text { Sata }\end{array}$ & & & & \\
\hline
\end{tabular}

Sumber: Data yang diolah dengan SPSS 23 (2017)

Pada tabel di atas diketahui bahwa ukuran perusahaan memiliki rata-rata 24,0000 dengan standar deviasi 5,91881. Nilai minimum dari ukuran perusahaan 15,00 dan nilai maksimum 30,00. Maka dikatakan bahwa perusahaan yang memiliki total aset di bawah 24,0000 merupakan perusahaan dengan skala lebih kecil di banding perusahaan yang ratarata total asetnya lebih dari 24,0000. Nilai standar deviasi yang lebih kecil di banding nilai rata-rata menunjukkan bahwa ukuran perusahaan satu dengan yang lain tidak terdapat perbedaan.

Leverage memiliki nilai mean sebesar 0,3297 dengan nilai minium sebesar 0,13 dan nilai maksimum sebesar 0,70 dan standar deviasi sebesar 0,14735. Hal ini berarti bahwa ratarata rasio leverage yang dimiliki perusahaan adalah sebesar 0,3297 atau 33\%, yang menandakan bahwa rata-rata perusahaan sampel memiliki kewajiban untuk setiap Rp. 1,00 aset yang dimilikinya. Standar deviasi yang lebih kecil di banding dengan nilai rata-rata menunjukkan bahwa leverage satu dengan yang lain tidak dapat perbedaan.

Profitabilitas yang di proksikan dengan ROA memiliki nilai mean sebesar 0,1504 dengan nilai maksimum 0,28 , nilai minimum 0.00 dan dengan standar deviasi 0,8484 . Hal ini berarti bahwa rata-rata profit perusahaan sampel adalah 0,1504 atau 15\%. Standar deviasi yang lebih kecil dari nilai rata-rata menunjukkan bahwa profitabilitas tidak berbeda jauh antara satu perusahaan dengan perusahaan lainnya. 


\section{[ACCOUNTING GLOBAL JOURNAL]

Market to book rasio memiliki nilai rata-rata (mean) sebesar 0,4826 dengan nilai maksimum 2,51, nilai minimum sebesar 0,00 dan standar deviasi 0,77686. Standar deviasi yang lebih kecil dari nilai rata-rata menunjukkan bahwa market to book ratio berbeda jauh antara satu perusahaan dengan perusahaan lainnya.

Kepemilikan mayoritas memiliki nilai rata-rata (mean) sebesar 1,0000 dengan nilai maksimum 1.00, nilai minimum sebesar 1,00 dan standar deviasi 0,00000. Nilai standar deviasi yang lebih kecil di banding nilai rata-rata, hal ini menunjukkan bahwa satu dengan yang lain tidak terdapat perbedaan.

Corporate social responsibility memiliki nilai rata-rata (mean) sebesar 0,6824 dengan nilai maksimum 0,81, nilai minimum sebesar 0,30 dan standar deviasi 0,17399. Nilai standar deviasi yang lebih kecil di banding nilai rata-rata, hal ini menunjukkan bahwa satu dengan yang lain tidak terdapat perbedaan.

Agresivitas pajak memiliki nilai rata-rata (mean) sebesar 0,2549 dengan nilai maksimum 0,39 , nilai minimum sebesar 0,22 dan standar deviasi 0,03479. Nilai standar deviasi yang lebih kecil di banding nilai rata-rata, hal ini menunjukkan bahwa satu dengan yang lain tidak terdapat perbedaan.

\section{Hasil Uji Asumsi Klasik}

Hasil Uji Normalitas

non parametric Kolmogorof-Smirnov

\begin{tabular}{|c|c|}
\hline & $\begin{array}{l}\text { Unstandrdized } \\
\text { Residual }\end{array}$ \\
\hline $\mathbf{N}$ & 32 \\
\hline Normal Parameters ${ }^{\text {a.b }}$ Mean & 0.0000000 \\
\hline Standart Deviation & 0.02551205 \\
\hline Most Extreme Differences Absolute & 0.106 \\
\hline Positive & 0.106 \\
\hline Negative & -0.088 \\
\hline Test Statistic & 0.106 \\
\hline Asymp. Sig. (2-tailed) & $0.200^{\text {c.d }}$ \\
\hline
\end{tabular}

Sumber: data sekunder yang diolah spss 23 (2016)

Berdasarkan tabel di atas dapat diketahui nilai Asymp sig dari Kolmogorof-Smirnov sebesar 0,200. Nilai hasil uji ini lebih besar dari 0,05, sehingga data berdistribusi normal. Hasil Uji Multikolonieritas

Coefficients $^{a}$

\begin{tabular}{|l|l|l|}
\hline Model & \multicolumn{2}{|c|}{ Collinerity Statistics } \\
\cline { 2 - 3 } & Tolerance & VIF \\
\hline
\end{tabular}




\begin{tabular}{|l|c|c|}
\hline (Constant) & \multicolumn{2}{|l|}{} \\
\hline Ukuran Perusahaan & 0.907 & 1,103 \\
\hline Laverage & 0.359 & 2,782 \\
\hline Profitabilitas & 0.325 & 3,076 \\
\hline Market To Book Rasio & 0.675 & 1,482 \\
\hline CSR & 0.841 & 1,189 \\
\hline
\end{tabular}

Sumber: data sekunder yang diolah SPSS 23 (2016)

Data tabel di atas menunjukkan bahwa tidak terjadi multikolinieritas, semua variabel independen memiliki nilai tolerance $>0,10$ dan nilai VIF $<10$, hal ini dapat di pastikan bahwa tidak ada korelasi antar variabel independen.

\section{Hasil Uji Autokorelasi}

\section{Model Summary}

\begin{tabular}{|c|c|c|c|c|c|}
\hline Model & $\mathbf{R}$ & $\begin{array}{c}\mathrm{R} \\
\text { Square }\end{array}$ & $\begin{array}{c}\text { Adjusted } \\
\mathrm{R}\end{array}$ & $\begin{array}{c}\text { Std. Of } \\
\text { the }\end{array}$ & $\begin{array}{c}\text { Durbin } \\
\text { Watson }\end{array}$ \\
\hline 1 & $0,680^{\mathrm{a}}$ & $\mathbf{0 4 6 2}$ & $\mathbf{0 , 3 5 9}$ & $\mathbf{0 , 2 7 8 6}$ & 1,546 \\
\hline
\end{tabular}

Sumber: data sekunder yang diolah spss 23 (2016)

Dari tabel di atas dapat di lihat nilai Durbin Watson yaitu 1,546. nilai ini akan di bandingkan dengan nilai tabel dengan tingkat signifikan $5 \%$ dengan jumlah total sampel 32 dan jumlah independen $6(k=6)$, maka dengan jumlah variabel independen tersebut dari tabel nilai Durbin Watson di dapatkan nilai $d l=1,3093$ dan $d u=1,5736$. Oleh karena nilai Durbin Watson sebesar 1,546 berada di antara nilai dl dan $d u(d l \leq d \leq d u)$, maka hasil nilai DW dinyatakan tidak ada keputusan. Untuk mengatasi masalah ini maka di lakukan uji autokorelasi run test uji run test adalah sebagai berikut:

Runs Test

\begin{tabular}{|l|l|}
\hline & $\begin{array}{l}\text { Unstandardized } \\
\text { Residual }\end{array}$ \\
\hline Test Value $^{a}$ & 0,00078 \\
\hline Cases $<$ Test Value & 16 \\
\hline Cases $>=$ Test Vaue & 16 \\
\hline Total Cases & 32 \\
\hline Number of Runs & 15 \\
\hline
\end{tabular}




\begin{tabular}{|l|l|}
\hline$Z$ & $-0,539$ \\
\hline $\begin{array}{l}\text { Asymp. Sig. (2- } \\
\text { tailed) }\end{array}$ & 0.590 \\
\hline
\end{tabular}

Sumber data yang diolah spss 23 (2016)

Dari tabel di atas terlihat pada nilai Asymp. Sig. (2-tailed) sebesar 0.590 dan nilai tersebut lebih besar dari 0,05 maka dapat di simpulkan bahwa tidak terjadi masalah autokorelasi, sehingga asumsi klasiknya terpenuhi.

\section{Hasil Uji Heterokedastisitas}

\begin{tabular}{|c|c|c|c|c|c|}
\hline \multirow[t]{2}{*}{ Model } & \multicolumn{2}{|c|}{$\begin{array}{c}\text { Unstandardized } \\
\text { Coefficients }\end{array}$} & \multirow{2}{*}{$\begin{array}{c}\text { Standardized } \\
\text { Coefficients } \\
\text { Beta }\end{array}$} & \multirow[t]{2}{*}{$\mathbf{T}$} & \multirow[t]{2}{*}{ Sig. } \\
\hline & B & $\begin{array}{l}\text { Std. } \\
\text { Error }\end{array}$ & & & \\
\hline (constant) & 0,002 & 0,020 & & 0,101 & 0,920 \\
\hline $\begin{array}{l}\text { Ukuran } \\
\text { perusahaan }\end{array}$ & 0,000 & 0,00 & $-0,014$ & $\begin{array}{l}- \\
0,095\end{array}$ & 0,925 \\
\hline Laverage & 0,049 & 0,026 & 0,448 & 1,913 & 0,067 \\
\hline Profitabilitas & $\begin{array}{l}- \\
0,088\end{array}$ & 0,047 & $-0,466$ & $\begin{array}{l}- \\
1,894\end{array}$ & 0,069 \\
\hline $\begin{array}{l}\text { Market to } \\
\text { book rasio }\end{array}$ & $\begin{array}{l}- \\
0,007\end{array}$ & 0,004 & $-0,343$ & $\begin{array}{l}- \\
2,005\end{array}$ & 0,055 \\
\hline CSR & 0,028 & 0,014 & 0,301 & 0,969 & 0,060 \\
\hline
\end{tabular}

Sumber: data sekunder yang diolah SPSS 23 (2016)

Dari tabel diatas menunjukkan bahwa probabilitas (sig) dalam tiap model regresi yang digunakan dalam penelitian ini $>0,05$ sehingga dapat dinyatakan bahwa tidak terjadi heterokedastisitas. Sehingga asumsi heterokedastisitas terpenuhi.

Hasil Pengujian Hipotesis

Hasil Analisis Regresi Berganda

coefficients $^{a}$

\begin{tabular}{|c|c|c|c|c|c|}
\hline \multicolumn{1}{|c|}{ Model } & \multicolumn{2}{|c|}{$\begin{array}{c}\text { Unstandardized } \\
\text { Coefficients }\end{array}$} & $\begin{array}{c}\text { Standardized } \\
\text { Coefficients }\end{array}$ & T & Sig. \\
\cline { 2 - 5 } & B & $\begin{array}{c}\text { Std. } \\
\text { Error }\end{array}$ & Beta & & \\
\hline 1 (constant) & 0,206 & 0,045 & & 4,572 & 0,235 \\
\hline
\end{tabular}




\begin{tabular}{|l|c|c|c|c|c|}
\hline $\begin{array}{l}\text { Ukuran } \\
\text { perusahaan }\end{array}$ & 0,000 & 0,001 & 0,043 & 0,287 & 0,042 \\
\hline Laverage & 0,118 & 0,057 & 0,500 & 2,083 & 0,009 \\
\hline Pofitabilitas & - & 0,103 & $-0,373$ & $-1,479$ & 0,181 \\
\hline $\begin{array}{l}\text { Market To } \\
\text { Book Rasio }\end{array}$ & 0,015 & 0,008 & $-0,357$ & $-2,038$ & 0,000 \\
\hline CSR & 0,051 & 0,031 & 0,255 & 1,627 & 0,116 \\
\hline
\end{tabular}

Sumber: data sekunder diolah data SPSS 23 (2016)

Berdasarkan tabel di atas maka persamaan regresi linier berganda yang di dapat adalah sebagai berikut:

$Y=0,083+0,004+0,158-0,133-0,007-0,380+0,166$

Persamaan regresi linier berganda di atas dapat diartikan bahwa:

1. Nilai konstanta bernilai positif sebesar 0,206 menunjukkan bahwa apabila seluruh variabel independen dianggap konstanta (0), maka rata-rata agresivitas pajak adalah sebesar $20,6 \%$

2. Ukuran perusahaan memiliki koefisien regresi berganda sebesar 0,000 menunjukkan bahwa setiap ukuran perusahaan independen sebesar $100 \%$ menaikkan agresivitas pajak sebesar $0 \%$

3. Laverage memiliki koefisien regresi sebesar 0,118 menunjukkan bahwa setiap pertambahan setiap laverage sebesar $100 \%$ menaikkan agresivitas pajak sebesar $11,8 \%$

4. Profitabilitas memiliki koefisien regresi sebesar -0,153 menunjukkan bahwa setiap pertambahan profitabilitas sebesar $100 \%$ menurunkan agresivitas pajak sebesar $15,3 \%$.

5. Market to book rasio memiliki koefisien regresi sebesar $-0,016$ menunjukkan bahwa setiap pertambahan market to book rasio sebesar $100 \%$ menurunkan agresivitas pajak sebesar $1,6 \%$.

6. Kepemilikan mayoritas tidak muncul dalam tabel karena kepemilikan mayoritas memiliki hasil yang sama.

7. CSR memiliki koefisien regresi sebesar 0,051menunjukkan bahwa setiap pertambahan CSR sebesar $100 \%$ menaikkan agresivitas pajak sebesar $5,1 \%$.

Hasil Uji Koefisien Determinasi $\left(\mathbf{R}^{2}\right)$

\begin{tabular}{|c|c|c|c|c|}
\hline Model & $\mathbf{R}$ & $\begin{array}{c}\mathbf{R} \\
\text { Square }\end{array}$ & $\begin{array}{c}\text { Adjust R } \\
\text { Square }\end{array}$ & $\begin{array}{c}\text { Std. Error of } \\
\text { the Estimate }\end{array}$ \\
\hline 1 & 0,680 & 0,462 & 0,359 & 0,02786 \\
\hline
\end{tabular}

Sumber: data sekunder yang diolah SPSS 23 (2016) 
Berdasarkan tabel 4.11 diketahui bahwa nilai Adjust R Square sebesar 0,449 yang berarti bahwa $45 \%$ variabel dependen yaitu agresivitas pajak dapat di jelaskan oleh variabel independen yaitu ukuran perusahaan, laverage, profitabilitas, market to book ratio, inventory intensity, kepemilikan mayoritas dan CSR. Sedangkan yang $55 \%$ di jelaskan oleh variabel yang lain.

\section{Hasil Uji $f$}

ANOVA

\begin{tabular}{|l|c|c|c|c|c|}
\hline Model & $\begin{array}{l}\text { Sum of } \\
\text { Square }\end{array}$ & $\begin{array}{l}\text { Mean } \\
\text { Square }\end{array}$ & F & Sig. \\
\hline 1 Regresion & 0,017 & 5 & 0,003 & $\begin{array}{l}4,47 \\
0\end{array}$ & $0,005^{\text {b }}$ \\
\hline Residual & 0,020 & 26 & 0,001 & & \\
\hline Total & 0,038 & 31 & & & \\
\hline
\end{tabular}

Sumber: data sekunder yang diolah spss 23 (2016)

Tabel uji F di atas menunjukkan bahwa nilai $F$ hitung sebesar 5,204 mempunyai probabilitas (sig) yang kurang dari $\alpha(0,001<0,05)$, hal ini menunjukkan bahwa ukuran perusahaan, laverage, profitabilitas, market to book rasio, inventory intensity, kepemilikan mayoritas dan CSR berpengaruh secara bersimultan terhadap agresivitas pajak.

\section{Hasil Uji t}

coefficients $^{a}$

\begin{tabular}{|l|c|c|c|c|c|}
\hline \multicolumn{1}{|c|}{ Model } & \multicolumn{2}{|c|}{$\begin{array}{c}\text { Unstandardized } \\
\text { Coefficients }\end{array}$} & $\begin{array}{c}\text { Standardized } \\
\text { Coefficients }\end{array}$ & T & Sig. \\
\cline { 2 - 5 } & B & $\begin{array}{c}\text { Std. } \\
\text { Error }\end{array}$ & \multicolumn{2}{|c|}{ Beta } & \\
\hline 1(constant) & 0,206 & 0,045 & & 4,572 & 0,000 \\
\hline $\begin{array}{l}\text { Ukuran } \\
\text { perusahaan }\end{array}$ & 0,000 & 0,001 & 0,043 & 0,287 & 0,047 \\
\hline $\begin{array}{l}\text { Laverage } \\
\text { Pofitabilitas }\end{array}$ & 0,118 & 0,057 & 0,500 & 2,803 & 0,776 \\
\hline $\begin{array}{l}\text { Market To } \\
\text { Book Rasio }\end{array}$ & 0,153 & 0,103 & $-0,373$ & - & 0,151 \\
\hline CSR & 0,051 & 0,031 & 0,255 & 1,627 & 0,116 \\
\hline
\end{tabular}

Sumber: data sekunder diolah data SPSS 23 (2016) 
Berdasarkan tabel uji t dapat di jelaskan sebagai berikut:

1. Pengaruh ukuran perusahaan terhadap agresivitas pajak

Berdasarkan tabel ukuran perusahaan memiliki koefisien regresi sebesar 0,000 dan memiliki t hitung sebesar 0,287 dan nilai probabilitas (sig) 0,776. Nilai t hitung $<\mathrm{t}$ tabel $(0,047<2,470)$ dan nilai probabilitas (sig) lebih kecil dari nilai $\alpha(0,047<0,05)$. Sehingga variabel ukuran perusahaan memiliki pengaruh terhadap agresivitas pajak dengan arah koefisien yang positif. Dengan demikian hipotesis satu $(\mathrm{H} 1)$ berpengaruh positif signifikan terhadap agresivitas pajak.

2. Pengaruh laverage terhadap agresivitas pajak

Berdasarkan tabel di atas laverage memiliki koefisien regresi sebesar 0,118 dan memiliki t hitung sebesar 2,083 dengan nilai probabilitas (sig) 0,009. Nilai hitung $\geq t$ tabel $(2,083 \geq 2,470)$ dan nilai probabilitas ( $\mathrm{sig}$ ) lebih kecil dari nilai < nilai $\alpha(0,776<0,05)$. Sehingga variabel laverage memiliki pengaruh terhadap agresivitas pajak dengan arah koefisien yang positif. Dengan demikian hipotesis dua $(\mathrm{H} 2)$ berpengaruh negatif signifikan terhadap agresivitas pajak.

3. Pengaruh profitabilitas terhadap agresivitas pajak

Berdasarkan tabel di atas bahwa profitabilitas memiliki koefisien regresi sebesar $-0,153$ dan nilai t hitung sebesar $-1,479$ dengan nilai probabilitas (sig) 0,151. Nilai t hitung lebih kecil dari t tabel $(0,153<2,470)$ dan nilai probabilitas (sig) lebih kecil dari nilai $\alpha(0,151 \geq 0,05)$. Sehingga variabel profitabilitas tidak memiliki pengaruh terhadap agresivitas pajak dengan arah koefisien positif. Dengan demikian hipotesis ketiga (H3) yang menyatakan profitabilitas berpengaruh negatif signifikan terhadap agresivitas pajak di tolak.

4. Pengaruh market to book rasio terhadap agresivitas pajak

Berdasarkan tabel di atas variabel market to book rasio memiliki koefisien regresi sebesar 0,016 dan nilai t hitung sebesar -2,038 dengan nilai probabilitas (sig) sebesar 0,052. Nilait hitung < t tabel $(-2,038<2,470)$ dan nilai probabilitas (sig) lebih besar dari nilai $\alpha(0,052=$ $0,05)$, sehingga variabel market to book rasio memiliki pengaruh terhadap agresivitas pajak dengan arah koefisien positif. Dengan demikian hipotesis keempat ( $\mathrm{H} 4$ ) yang menyatakan bahwa market to book rasio berpengaruh positif signifikan terhadap agresivitas pajak di terima.

5. Pengaruh corporate social responsibility terhadap agresivitas pajak

Berdasarkan tabel di atas bahwa variabel CSR memiliki koefisien regresi sebesar 0,051 dan nilai t hitung sebesar 1,627 dengan nilai probabilitas (sig) sebesar 0,116. Jika nilai t hitung lebih kecil dari nilai t tabel $(1,627<2,470)$ dan nilai probabilitas $(s i g)$ lebih besar dari nilai $\alpha$ $(0,116<0,05)$, sehingga variabel CSR tidak memiliki pengaruh terhadap agresivitas pajak dengan arah koefisien positif. Dengan demikian hipotesis keenam (H6) yang menyatakan bahwa variabel corporate social responsibilty berpengaruh negatif signifikan terhadap agresivitas pajak di terima. 


\section{KESIMPULAN}

Berdasarkan hasil penelitian ini untuk mengetahui tentang pengaruh ukuran perusahaan, laverage, profitabilitas, market to book rasio, kepemilikan mayoritas dan corporate social resonsibility terhadap agresivitas pajak, maka dapat di simpulkan bahwa:

Ukuran perusahaan berpengaruh secara signifikan terhadap pajak. Hasil penelitian tersebut menunjukkan bahwa semakin tinggi ukuran perusahaan maka akan semakin tinggi pula agresivitas pajak perusahaan. Hasil penelitian ini konsisten dengan hasil penelitian yang dilakukan oleh Kuriah dan Asyik (2016) yang menyatakan bahwa ukuran perusahaan bepengaruhterhadap agresivitas pajak yang dilakukan oleh perusahaan.

Laverage berpengaruh signifikan terhadap agresivitas pajak. Hasil penelitian tersebut menunjukkan bahwa laverage perusahaan yang semakin tinggi akan membuat semakin tinggi agresivitas pajak. Hasil penelitian ini konsisten dengan hasil penelitian yang dilakukan oleh Fikriyah (2014) yang menyatakan bahwa tidak ada pengaruh yang kuat antara laverage perusahaan terhadap tingkat agresivitas pajak.

Profitabilitas tidak berpengaruh terhadap agresivitas pajak. Hasil penelitian tersebut menunjukkan bahwa perusahaan yang memiliki profitabilitas yang naik tiap tahun akan lebih menjaga nama baik dan menjauhi keputusan yang beresiko bagi keberlangsungan usaha perusahaan salah satunya keputusan tindakan agresivitas pajak. Penelitian ini konsisten dengan hasil penelitian yang dilakukan oleh Cahyono, dkk. (2016) yang menyatakan bahwa profitabilitas tidak berpengaruh terhadap agresivitas pajak.

Market to book rasio berpengaruh terhadap agresivitas pajak. Market to book rasio digunakan untuk melihat dan mengetahui peluang pertumbuhan perusahaan dimasa yang akan datang. Ketiak pertumbuhan saham menurun, ini akan diikuti pula penurunan minat investor untuk berinvestasi. Hal ini akan membuat perusahaan tidak mau melakukan agresivitas. Penelitian ini konsisten dengan penelitian yang dilakukan oleh Nusantari (2015) yang menyatakan bahwa market to book rasio adanya pengaruh negatif terhadap agresivitas pajak.

Corporate social responsibility tidak berpengaruh terhadap agresivitas pajak. Perusahaan membayar pajak secara wajar sesuai hukum dinegara manapun perusahaan beroperasi, sehingga agresivitas pajak tidak akan dlakukan. Hasil penelitian ini konsisten dengan hasil penelitian yang dilakukan oleh Jessica dan Toly (2014) yang menyatakan bahwa corporate social responsibility tidak memiliki pengaruh terhadap agresivitas pajak, semakin tinggi tingkat CSR maka semakin tinggi tingkat agresivitas.

\section{Saran}


Berdasarkan simpulan di atas, maka terdapat beberapa saran yang mungkin dapat di jadikan sebagai bahan pertimbangan sebagai berikut: 1 . Menambahkan variabel penelitian yang berkaitan erat dengan agresivitas pajak, karena masih ada banyak faktor-faktor yang mempengaruhi agresivitas pajak seperti yang disaran kan oleh Gemilang (2017). 2. Penelitian selanjutnya di harapkan dapat menambahkan sampel dan memperpanjang periode penelitian perusahaan dari sektor lain, karena menambahkan sampel bisa memperluas sampel yang lebih besar seperti yang disarankan oleh Adisamartha, dan Noviari (2015). 3. Penelitian selanjutnya di harapkan untuk menambahkan pengukuran lain, misalnya: menggunakan pengukuran Cash EffextiveTax Rates (CETR), karena pengukuran ini juga bisa membantu untuk menentukan hasil dari variabel-variabel penelitian diatas, seperti yang di sarankan oleh Siregar dan Widyawati (2016).

\section{DAFTAR PUSTAKA}

B. Rohmansyah. 2016. Determinan Kinerja Perusahaan Terhadap Agresivitas Pajak (Studi Pada Perusahaan Sektor Perbankan Yang Terdaftar Di Bursa Efek Indonesia Periode 2010-2014). Universitas Muhammadiyah Tangerang.

C. L. Putri, dan M. F. Lautania. 2016. Pengaruh Capital Intensity, Inventry Intensity Rasio, Ownership Structure Dan Profitability Terhadap Effective Tax Rate (ETR). Jurnal IImiah Mahasiswa Ekonomi Akuntansi (JIMIKA). Vol. 1 (1). Halaman 101-119. Universitas Syiah Kuala.

D. Ardyansah, dan Zulaikhah. 2014. Pengaruh Size Laverage, Profitability, Capital Intnsity Ratio Dan Komisaris Independen Terhadap Effective Tax Rate (ETR). Journal Of Accounting Volume 3(2) 2014, Halaman 1-9. Universitas Diponegoro. Semarang.

D. D. Cahyono, R. Andini, dan K. Raharjo. 2016. Pengaruh Komite Audit, Kepemilikan Institutional, Dewan Komisaris, Ukuran Perusahaan (size), Leverage (DER), Dan Profitabilitas (ROA) Terhadap Tindakan Penghindaran Pajak (Tax Avoidance) Pada Perusahaan Listing BEI Periode Tahun 2011-2013. Journal of Accounting, Volume 2(2) :03-2016

D. H. Pradipta, dan Supriyadi. 2016. Pengaruh Corporate Social Responsibility, Profitabilitas, Leverage, Dan Komisaris Independen Terhadap Praktik Penghindaran Pajak. Universitas Gajah Mada. Yogyakarta.

D. N. Gemilang. 2017. Pengaruh Laverage, Profitabilitas, Ukuran Perusahaan, Dan Capital Intensity Terhadap Agresivitas Pajak Perusahaan (Studi Empiris Pada Perusahaan Property dan Real Estate Yang Terdaftar Di BEI Pada Tahun 2013-2015). Fakultas Ekonomi Dan Bisnis Islam. Institut Agama Islam Negeri Surakarta. Surakarta. 
D. Ratmono, dan W. M. Sagala. 2015. Pengungkapan Corporate Social Responsibility (CSR) Sebagai Sarana Legitimasi: Dampaknya Terhadap Tingkat Agresivitas Pajak. Jurnal Nominal 4(2): 2015. Universitas Diponegoro.

E. A. Purwanggono. 2015. Pengarauh Corporate Social Responsibility Dan Kepemilikan Mayoritas Terhadap Agresivitas Pajak (Studi Empiris pada Perusahaan Manufaktur yang Terdaftar di BEI tahun 2011-2013). Skripsi. Universitas Diponegoro.

F. Anita. 2015. Pengaruh Corporate Social Responsibility, Laverage, Likuiditas, Dan Ukuran Perusahaan Terhadap Agresivitas Pajak (Studi Empiris pada Perusahaan Real Estate Dan Property yang Terdaftar di BEI 2010-2013). JOM Fekom 2(2): 10-15.

Fikriyah. 2014. Analisis Pengaruh Likuiditas, Laverage, profitabilitas, dan Karakteristik Kepemilikan Terhadap Agresivitas Pajak (studi pada Perusahaan Sektor Pertambangan yang Terdaftar di BEI tahun 2010-2012). Skripsi. UIN Maliki. Malang.

Ghozali, I dan Chariri A. (2014). Teori Akuntansi Internasional Finansial Reporting System (IFRS). Edisi Keempat. Badan Penerbit Universitas Diponegoro. Semarang.

Ghozali, I. 2016. Aplikasi Analisis Multivariate dengan Program IMB SPSS 23. Edisi Kedelapan. Universitas Diponegoro. Semarang.

H. L. Kuriah, dan N. F. Asyik. 2016. Pengaruh Karakteristik Perusahaan Dan Corporate Social Responsibility Terhadap Agresivitas Pajak. Jurnal Ilmu dan Riset Akuntansi 5(3): 03-16. Sekolah Tinggi Ilmu Ekonomi Indonesia (STIESIA) Surabaya.

H. R. M. Tarigan. 2016. Pengaruh Corporate Social Responsibility Dan Profitabilitas Terhadap Agresivitas Pajak. Fakultas Ekonomi Dan Bisnis. Universitas Komputer Indonesia.

I. B. P. F. Adisamartha, dan N. Noviari. 2015. Pengaruh Likuiditas, Leverage, Intensitas Persediaan Dan Intensitas Aset Tetap Pada Tingkat Agresivitas Wajib Pajak Badan. Universitas Udayana Bali, Indonesia.

I. G. A.C. Maharani, dan K. A. Suardana. 2014. Pengaruh Corporate Governance, Profitabilitas Dan Karakteristik Pada Tax Avoidance Perusahaan Manufaktur. EJurnal Akuntansi Univeritas Udayana 9.2 (2014) : 952-539.

Jessica, dan A. A. Toly. 2014. Pengaruh Pengungkapan Corporate Social Responsibility Terhadap Agresivitas Pajak. Tax \& Accounting Review 4(1): 2014. Universitas Kristen Petra. 


\section{[ACCOUNTING GLOBAL JOURNAL] E ISSN}

J. Hadi, dan Y. Mangoting. 2014. Pengaruh Kepemilikan Dan Karakteristik Dewan Terhadap Agresivitas Pajak. Tax \& Accounting Review 4(2): 2014. Universitas Kristen Petra.

N. Dewi. 2016. Pengaruh Karakter Eksekutif, Karakteristik Perusahaan, Dan Pengungkapan Tanggung jawab Terhadap Penghindaran Pajak. JOM Fekom 3(1): 02-16.

N. I. Nusantari, N. F. Nuzula, dan A. Darono.2015. Pengaruh Agresivitas Pajak Terhadap Pengungkapan Corporate Social Responsibility(CSR) (Studi pada Perusahaan yang Terdaftar dalam Indexs Sri Kehati tahun 2011-2013). Perpajakan (JAB) 5(2): 2015.

N. K. Asri, D. F. Puspa, dan M. Hamdi. 2016. Pengaruh Corporate Social Responsibility Dan Corporate Governance Terhadap Agresivitas Pajak Perusahaan Manufaktur Yang Listing Di Bursa Efek Indonesia (BEI) Periode 2010-2014. Jurnal. Universitas Bung Hatta.

Nurfadilah, H. Mulyati, M. Purnamasari, H. Niar. 2016. Pengaruh Leverage, Ukuran Perusahaan, Dan Kualitas Audit, Terhadap Penghindaran Pajak (Studi Empiris Pada Perusahaan Manufaktur Yang Terdaftar di Bursa Efek Indonesia Tahun 2011-2015). STIE Ahmad Dahlan Jakarta.

Sugiyono. 2016. Metode Penelitian Kuantitatif, Kualitatif dan Kombinasi (MIXED METHODS). Cetakan Kedelapan. Anggota Ikatan Penerbit Indonesia (IKAPI).

Rinaldi, dan C. Cheisviyanny. 2015. Pengaruh Profitabilitas, Ukuran Perusahaan Dan Kompensasi Rugi Fiskal Terhadap Tax Avoidance (Studi Empiris Pada Perusahaan Manufaktur Yang Tedaftar Di BEI tahun 2010-2013). Universitas Negeri Padang.

R. Siregar, dan D. Widyawati. 2016. Pengaruh Karakteristik Perusahaan Terhadap Penghindaran Pajak Pada Perusahaan Manufaktur Di BEI. Jurnal IImu dan Riset Akuntansi vol 5(2):02-16. Sekolah Tinggi Ekonomi Indonesia (STIESIA). Surabaya.

R. Yolanda, D. F. Puspa, Ethika. 2016. Pengaruh Return On Asets, Ukuran Perusahaan, Dan Sales Growth Terhadap Penghindaran Pajak (Studi pada Perusahaan Manufaktur yang terdaftar di BEI tahun 2010-2014). 
Seprini. 2016. Tindakan Pajak Agresif Pengaruh Good Corporate Governance Dan Corporate Social Responsibility Terhadap (Studi pada Perusahaan Pertambangan yang Terdaftar di BEI tahun 2011-2013). JOM Fekom 3(1): 02-16.

T. N. M. Ulfa, 2016. Pengaruh Profitabilitas, Mekanisme Good Corporate Governance dan Corporate Social Responsibility Terhadap Tindakan Pajak Agresif (Studi Perusahaan Pertambangan Yang Terdaftar di Bursa Efek Indonesia periode 2010-2014). Universitas Muhammadiyah. Yogyakarta.

W. Y. Agusti. 2014. Pengaruh Profitabilitas Dan Corporate Governance Terhadap Tax Avoidance (Studi Empiris Pada Perussahaan Manufaktur Yang Terdaftar Di BEI Tahun 2009-2012). Artikel IImiah. Universitas Negeri Padang.

Yoehana M. 2013. Analisis Pengaruh Corporate Social Responsibility Terhadap Agresivitas Pajak (Studi Empiris pada Perusahaan Manufaktur yang Terdaftar di Bursa Efek Indonesia tahun 2010-2011) Skripsi. Universitas Diponegoro. Semarang. 